\title{
PRESENTACIÓN
}

\section{La portada de Asclepio en el tercer milenio}

Con el fascículo 1 de este volumen LIII de Asclepio, la portada de la revista se renueva, tras mantener durante cerca de dos décadas el rostro clásico del dios sanador como protagonista único de su cubierta.

Dos motivos nos han decidido a tal cambio: uno de índole simbólica, el otro de condición testimonial.

Inauguramos, precisamente con este volumen LIII, no sólo un nuevo siglo sino también el tercer milenio de nuestra era. ¿No es todo ello ocasión propicia para entrar en este incógnito escenario temporal cambiando el aspecto de Asclepio, dedicando parte de su portada a la exposición de su contenido, a desmitificar — valga el verbola leyenda post-homérica de su nombre en aras de una concepción tan rigurosa pero menos venerativa y exclusiva de su figura?

De poco valdría tal cambio material si no fuese acompañado —aquí la condición testimonial del hecho- de una actitud, de un compromiso: el intento de que, desde ahora, aunque sea paulatinamente, las páginas de la revista renueven también su contenido, en pro del rigor científico, de la concisión, de la variedad de sus trabajos, de todo aquello que, llevándola a una nueva etapa, la haga digna de llegar, si es posible, a esa lejana meta de su centenario.

Símbolo y testimonio, renovación y compromiso. Que desde su posición en la nueva portada, disminuido en tamaño pero siempre prenda de su consagración a la investigación histórica, el hijo de Quirón propicie el éxito de nuestra aventura y muestre su gratitud a quienes colaboraron en el diseño de su nueva imagen.

Redacción 